\title{
Physiological response of freshwater microalga (Chlorella vulgaris) to triazine and phenylurea herbicides
}

C Rioboo, O González, C Herrero, A Cid, ${ }^{1}$

Aquatic Toxicology, Volume 59, Issues 3-4, 24 September 2002, Pages 225-235

Received 4 May 2001, Revised 20 July 2001, Accepted 18 October 2001, Available online 27 November 2001

DOI: 10.1016/S0166-445X(01)00255-7

\begin{abstract}
The effects of two herbicides used wide-spread, isoproturon (phenylurea) and terbutryn (triazine), on growth, dry weight, elemental composition, photosynthetic pigments and protein content, and cell volume assayed by flow cytometry in the freshwater microalgae Chlorella vulgaris were studied. Different parameters for algal activity show widely different sensitivities to these aquatic pollutants. After $96 \mathrm{~h}$ of herbicide exposure, terbutryn was the strongest inhibitor of growth, giving an $\mathrm{EC}_{50}$ value for growth twice lower than that for isoproturon cultures $\left(E C_{50}\right.$ terbutryn=0.097 $\mu \mathrm{M} ; E_{50}$ isoproturon=0.199 $\left.\mu \mathrm{M}\right)$. However, lower concentrations of the triazine herbicide provoked an increase in the cellular density and growth rate of this microalga, not observed in the phenylurea-treated cultures. Cellular volume and dry weight of $C$. vulgaris cells were increased strongly in the presence of isoproturon and terbutryn. Other cellular parameters, such as pigment and protein content, were stimulated with both herbicides at higher concentrations.
\end{abstract}

\section{Keywords}

Microalga; Herbicide; Triazine; Phenylurea; Toxic effects

\section{Introduction}

Most phytotoxicological research with herbicides has been conducted on target plants (i.e. efficacy studies on weeds). Little data exist on the effects of these pollutants may have in aquatic systems (Caux et al., 1996), excepting the triazine atrazine. The sensitivity of algae to many herbicides is very high, and a better understanding of their environmental effects is

\footnotetext{
${ }^{1}$ Laboratorio de Microbioloxía, Facultad de Ciencias, Universidade da Coruña, Rúa Alejandro de la Sota no. 1, 15008 A Coruña, Spain
} 
probably acquired by using test species representing non-target groups (Haglund, 1997). As the major primary producers in freshwater ecosystems, microalgae play a pivotal role in the functioning of a healthy ecosystem. Because of their short generation times, microalgae respond rapidly to environmental changes and, thus, may report impacts on higher organisms, which generally respond on longer time scales (McCormick and Cairns, 1994). Furthermore, microalgal tests are generally sensitive, rapid and low-cost effective (Sosak-Swiderska et al., 1998). For these reasons, the use of microalgal toxicity tests is increasing, and today these tests are frequently required by authorities for notifications of chemicals and are also increasingly being used to manage chemical discharges (Mayer et al., 1997). For example, algal toxicity tests of chemicals are mandatory tests for notification of chemicals in the European Union countries (Organization for Economic Cooperation and Development (OECD), Algae growth inhibition test, Test Guidelines, OECD Guideline for Testing of Chemicals, Paris, no. 201 , p. 14, 1984). Other fields of use for microalgae in toxicity assessment are industrial wastewaters and leachates from waste deposits (Sosak-Swiderska et al., 1998).

Isoproturon (3-(4-isopropylphenyl)-1,1-dimethylurea) is a pre- or post-emergence systemic herbicide, commonly used to control annual grasses and broad-leaved weeds in barley, wheat and rye, relatively soluble in water (Tomlin, 1994). Very little research has been devoted to the study of isoproturon and its toxic effects on primary producers in freshwater systems (Pérés et al., 1996).

Terbutryn ( $N$-tert-butyl- $N^{4}$-ethyl-6-methylthio-1,3,5-triazine-2,4-diamine) is also a pre- or postemergence systemic herbicide. It is used to control most grasses and many annual broadleaved weeds in winter cereals, potatoes, legumes, sunflowers, maize, sugar cane and citrus fruit. Furthermore, it is used as an aquatic herbicide for controlling submerged and free-floating weeds and algae in water courses ( Tomlin, 1994).

Photosynthesis is a primary and effective target site for over $50 \%$ of the commercially available herbicides (Singh et al., 1997). Isoproturon and terbutryn have been used as herbicides in large amounts since the mid-1980s (Larsen et al., 2000).

These herbicides of urea (isoproturon) and triazine (terbutryn) classes act biochemically by displacing a plastoquinone $\left(Q_{B}\right)$ from its binding site in the D1 protein of photosystem II (PS II), i.e. their primary site of action being inhibition of the Hill reaction of photosynthetic electron transport (Cremlyn, 1991).

In this study, herbicide

phytotoxicity assessment was conducted in the laboratory on the freshwater green algae (Chlorella vulgaris), one of the most commonly used species in microalgal toxicity tests ( Nalewajko and Olaveson, 1998). Parameters, such as growth and photosynthetic pigment content, frequently used in microalgal toxicity assays were examined. Furthermore, cell volume analysed by flow cytometry was used to compare with cell dry weight data.

\section{Materials and methods}




\subsection{Microalgal cultures}

Chlorella vulgaris Beijerinck (Oocystaceae) was obtained from the Culture Collection of Algae and Protozoa of the Institute of Freshwater Ecology (Cumbria, UK) (strain CCAP 211/11B) and was maintained in a Bristol medium (Brown et al., 1967). The inoculum was taken from a 3day-old culture, with the aim to use cells growing in a logarithmic phase for all experiments. Cultures were grown in autoclaved $\left(121^{\circ} \mathrm{C}, 20 \mathrm{~min}\right.$ ) 500-ml Pyrex glass bottles containing 300 $\mathrm{ml}$ of medium. Microalgal cultures were maintained at $18 \pm 1{ }^{\circ} \mathrm{C}$ and $68.25 \mu \mathrm{mol}$ photon $\mathrm{m}^{-2} \mathrm{~s}^{-1}$, with a dark:light cycle of 12:12 h. Initial cell density for each experiment was $9 \times 10^{6} \mathrm{cells}^{-1}$. Terbutryn and isoproturon were Riedel-de Häen Pestanal (RdH Laborchemikalien GmbH \& Co.; Seelze, Germany) standards for environmental analysis. Herbicide stock solutions were prepared by dissolving granulated herbicides in 100\% methanol. Terbutryn concentrations assayed were $0.025,0.05,0.10$ and $0.20 \mu \mathrm{M}$, while isoproturon concentrations assayed were $0.05,0.10,0.25$ and $0.50 \mu \mathrm{M}$. Final methanol concentrations for each treatment did not exceed $0.05 \%(\mathrm{v} / \mathrm{v})$, and no measurable effects on growth or on other parameters assayed were observed when this concentration of methanol was tested in the absence of herbicides. Cultures without herbicide were included as control in all experiments. All experiments were carried out in triplicate for $96 \mathrm{~h}$ as has already been indicated for toxicity assays with microalgae (Walsh and Merril, 1984).

\subsection{Measurement of growth}

Growth of the microalgal cultures was measured by counting daily culture aliquots in a Neubauer haemocytometer using an Eclipse E400 microscope (Nikon, Japan), and growth rates $(\mu)$, expressed in day-1, were calculated by the usual formula:

$$
\mu=\left[\left(\ln N_{\mathrm{t}}-\ln N_{0}\right)\right] / \ln 2\left(t-t_{0}\right)
$$

where $N$ is the cell density at time $t$ (expressed in

days) after herbicide exposure.

The most common parameter used in toxicity assays is the $\mathrm{EC}_{50}$, i.e. the concentration of the tested substance that decreases the growth rate by $50 \%$. EC $\mathrm{C}_{50}$ values after 48 and $96 \mathrm{~h}$ of herbicide exposure were obtained by graphic interpolation from concentration-response curves. Growth rate data analysis was carried out using the Regression Wizard (SigmaPlot 4.0, SPSS Inc.) software. Data were fitted by a non-linear regression three parameters sigmoidal curve, using Marquardt's algorithm which theoretical mathematical function is:

$$
y=a /\left[1+\exp \left(-\left(x-x_{0}\right) / b\right)\right] \text { where } y \text { is the percentage of the growth rate variation }
$$

respect to the control (cultures without pesticide); xis the pesticide concentration (expressed as $\mu \mathrm{M})$; the three parameters for this function determine the high value $(a)$, the width of the transition $(b)$, and the $x$ value at which the function is $50 \%$ of the functions amplitude ( $x_{0}$, closely related to $\mathrm{EC}_{50}$ ).

\subsection{Determination of cell volume}


Microalgal cellular volume variations were determined after $96 \mathrm{~h}$ of herbicides exposure by flow cytometry, since an increase in the forward light scatter (FSC) signal can be correlated with an increase in cell volume (Shapiro, 1995). Aliquots of microalgal cultures were analyzed in a FACScan flow cytometer (Becton Dickinson Instruments, San José, CA), equipped with an argon-ion excitation laser (blue light, $488 \mathrm{~nm}$ ). At least $10^{4}$ cells were analysed per culture. Data collection was performed using the list-mode. The mean of forward scatter signal distributions was provided by the instrument software (LYSIS II program; Becton Dickinson Instruments, San José, CA). Data on the forward scatter of the cells, related to cell volume, were expressed as a percentage of the control cells signal (arbitrary units) according to the equation of Reader et al. (1993):

$$
\% V=100-\left[100\left(V_{\mathrm{c}}-V_{\mathrm{t}}\right) / V_{\mathrm{c}}\right]
$$

where $\% V$ is the percentage of the FSC signal of $C$.

vulgaris cells; $V_{\mathrm{c}}$ is the mean FSC signal of control cells; and $V_{\mathrm{t}}$ is the mean FSC signal of herbicide-treated cells.

\subsection{Dry weight, carbon/nitrogen ratio and protein content}

Samples for these analysis were taken after $96 \mathrm{~h}$ of herbicide exposure. Microalgal cells were harvested by centrifugation at $3000 \times g$ and frozen at $-70^{\circ} \mathrm{C}$ prior to lyophilisation for $24 \mathrm{~h}$. The dry weight was determined according to Utting (1985). Carbon and nitrogen content were obtained with an elemental analyser (Carlo Erba CHNS-O 1108).

Proteins were determined from the data of nitrogen content, using the conversion factor, 5.8, described byGnaiger and Bitterlich (1984), instead of the classical conversion factor, 6.25 (FAO/WHO, 1973), since it was demonstrated that this new conversion factor is better for different kind of samples, including algae, bacteria, protozoan and invertebrates (Gnaiger and Bitterlich, 1984).

\subsection{Photosynthetic pigments content}

C. vulgaris photosynthetic pigment contents were determined from spectrophotometric measurements in a Shimadzu UV-160 (Japan) of 100\% methanol extracts using the equations described in Lichtenthaler (1987).

Data were statistically analysed by an overall one-way analysis of variance (ANOVA) and, when differences observed were significant, the means were compared by multiple range Duncan test, at a level of significance of $0.05(P<0.05)$.

\section{Results}

\subsection{Isoproturon}

\subsubsection{Growth}


This herbicide affected the growth of the freshwater microalga $C$. vulgaris ( Fig. 1; Table 1). After $48 \mathrm{~h}$, all microalgal cultures exposed to isoproturon showed a decrease in the growth rate with respect to the control cultures $(P<0.05)$ ( Table 1). However, no significant differences were observed between control cultures and cultures with the minimum concentration assayed, 0.05 $\mu \mathrm{M}(P<0.05)$ after $96 \mathrm{~h}$; growth rates were 0.82 and 0.75 day $^{-1}$, respectively. Growth decreased as isoproturon concentration increased in the cultures; $0.50 \mu \mathrm{M}$ drastically inhibiting microalgal growth, growth rate being below 0 (-14 day exp 1) after $96 \mathrm{~h}$ ( Table 1).

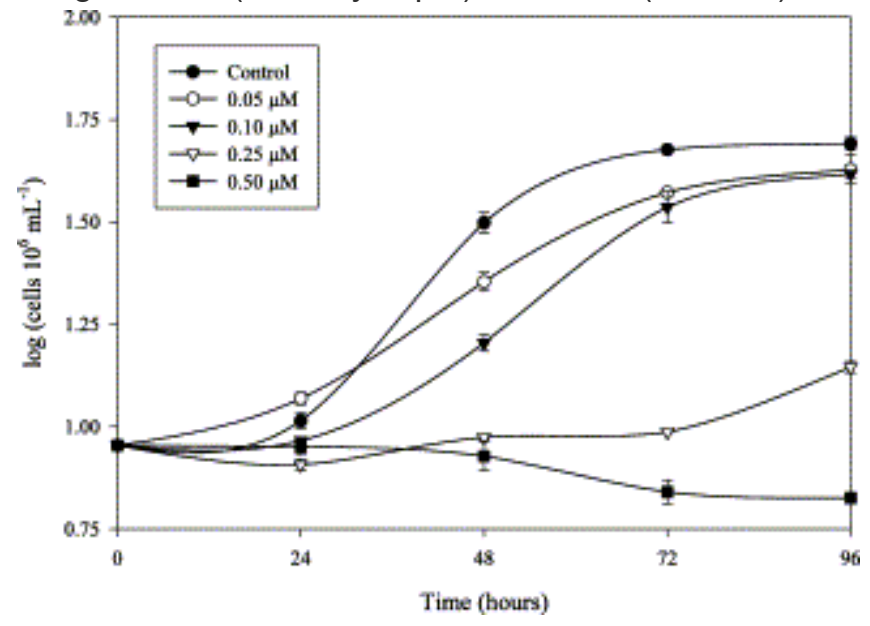

Fig. 1.

Growth curves of cultures of $C$. vulgaris exposed to different isoproturon concentrations $(\mu \mathrm{M})$. Data are given as mean values \pm S.D. of the means.

Table 1.

Growth rate (GR) after 48 and 96 h, and dry weight, cell volume, protein content, and carbon/nitrogen ratio obtained in cultures of $C$. vulgaris exposed to different isoproturon concentrations after $96 \mathrm{~h}$

\begin{tabular}{lllllll}
$\begin{array}{l}\text { Isoproturon } \\
(\mu \mathrm{M})\end{array}$ & $\begin{array}{l}48 \mathrm{~h} \mathrm{GR}(\mu) \\
\left(\mathrm{day}^{-1}\right)\end{array}$ & $\begin{array}{l}96 \mathrm{~h} \mathrm{GR}^{-1}(\mu) \\
\left(\mathrm{day}^{-1}\right)\end{array}$ & $\begin{array}{l}\text { Dry weight } \\
\left(\mathrm{pg} \mathrm{cell}^{-1}\right)\end{array}$ & $\begin{array}{l}\text { Cell } \\
\text { volume } \\
(\% \mathrm{FSC})\end{array}$ & $\begin{array}{l}\text { Protein } \\
\text { content }(\mathrm{pg} \\
\left.\text { cell }^{-1}\right)\end{array}$ & $\mathrm{C} / \mathrm{N}$ \\
\hline 0 & $0.90 \pm 0.03$ & $0.82 \pm 0.01$ & $4.48 \pm 0.09$ & $100 \pm 0.08$ & $2.27 \pm 0.09$ & $5.54 \pm 0.06$ \\
\hline 0.05 & $0.66 \pm 0.02$ & $0.75 \pm 0.03$ & $5.71 \pm 0.77$ & $141 \pm 6.68$ & $2.99 \pm 0.04$ & $5.43 \pm 0.06$ \\
\hline 0.10 & $0.42 \pm 0.02$ & $0.73 \pm 0.02$ & $4.27 \pm 0.15$ & $164 \pm 6.70$ & $2.66 \pm 0.07$ & $5.36 \pm 0.09$ \\
\hline 0.25 & $0.04 \pm 0.01$ & $0.21 \pm 0.01$ & $10.23 \pm 0.31$ & $270 \pm 5.45$ & $5.59 \pm 0.11$ & $5.21 \pm 0.12$ \\
\hline 0.50 & $-0.04 \pm 0.01$ & $-0.14 \pm 0.02$ & $14.47 \pm 1.00$ & $294 \pm 5.80$ & $8.59 \pm 0.14$ & $4.59 \pm 0.07$
\end{tabular}

Data are given as mean values \pm S.D. of the means.

Microalgal growth is characterized by a sigmoid or logistic function(Schanz and Zahler, 1981). In the present study, the growth of the microalgal cultures was fitted to the parameters of a logistic function, except for the 0.25 and $0.50 \mu \mathrm{M}$ cultures (Fig. 1). C. vulgaris cultures showed a prolonged lag phase after exposure to isoproturon, reaching the stationary phase later than control.

The concentration-response curves and their mathematical functions are shown in Fig. 2. In the isoproturon cultures, the $\mathrm{EC}_{50}$ value after $96 \mathrm{~h}$ of herbicide exposure was twice the $\mathrm{EC}_{50}$ for the cultures exposed $48 \mathrm{~h}$ to isoproturon (Fig. 2). 


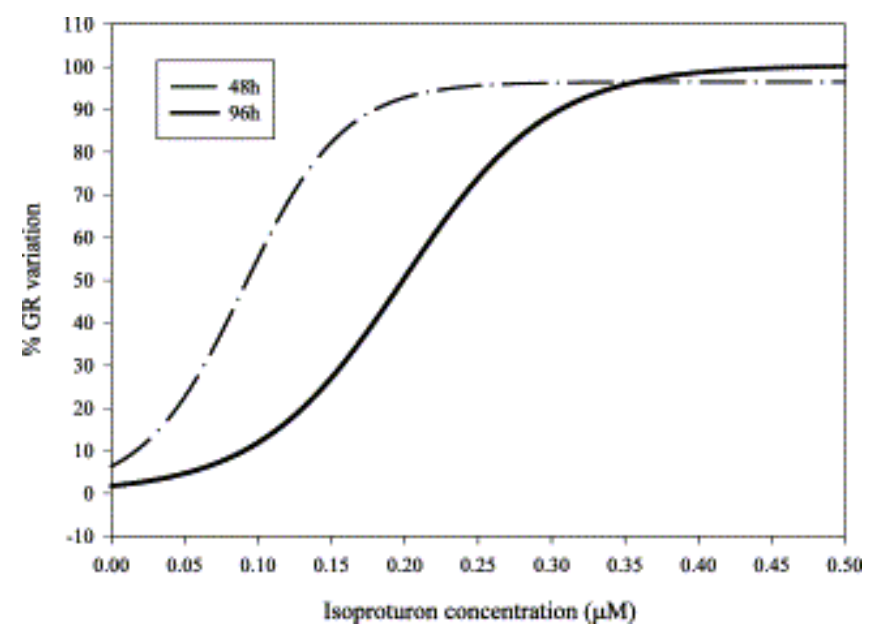

Fig. 2.

Concentration-response curves represented by growth rate (GR) variation respect to the control of cultures of $C$. vulgarisvs. different isoproturon concentrations $(\mu \mathrm{M})$ after 48 and $96 \mathrm{~h}$ of herbicide exposure. 48 h: $y=96.434 /\left(1+\exp (-(x-0.090) / 0.034)(r=0.99) \mathrm{EC}_{50}=0.092 ; 96 \mathrm{~h}: y=100.321 /(1+\exp (-(x-\right.$ $0.199) / 0.049)(r=0.99) \mathrm{EC}_{50}=0.199$.

\subsubsection{Cell volume}

High isoproturon concentrations caused an increase in the FSC signal, related to an increase in the cell volume of $C$. vulgaris. After $96 \mathrm{~h}$ of herbicide exposure, the most drastic increase in cell volume was detected at isoproturon concentrations of 0.25 and $0.50 \mu \mathrm{M}(270$ and $294 \%$, respectively) relative to control $(P<0.05)(100 \%)$ ( Table 1$)$.

\subsubsection{Dry weight, carbon/nitrogen ratio and protein content}

Concentrations of 0.25 and $0.50 \mu \mathrm{M}$ lead to a significant increase in cellular dry weight (DW) after $96 \mathrm{~h}(P<0.05)$, being twice to three times greater than the DW of the control culture cells (4.48 pg cell-1) ( Table 1).

Carbon and nitrogen percentages in dry biomass, determined after $96 \mathrm{~h}$ of culture, showed that the $\mathrm{C} / \mathrm{N}$ ratio decreased significantly $(\mathrm{P}<0.05)$ in cultures with 0.25 and $0.50 \mu \mathrm{M}(5.21$ and 4.59 , respectively) in comparison with the ratio obtained in control cultures (5.54) ( Table 1).

Cellular protein content after $96 \mathrm{~h}$ of isoproturon exposure showed a significant increase $(P<0.05)$ when the herbicide concentrations were higher than $0.10 \mu \mathrm{M}$, with a maximum value of $8.59 \mathrm{pg}$ cell-1 in cultures exposed to an isoproturon concentration of $0.50 \mu \mathrm{M}$, being nearly four times higher than the protein content of the control cells $(2.27 \mathrm{pg}$ cell-1) ( Table 1$)$.

\subsubsection{Photosynthetic pigments content}

After $96 \mathrm{~h}$ of isoproturon exposure, cellular chlorophyll $a$ and $b$ contents were more affected than total carotenoid content by the addition of the herbicide ( Fig. 3). Maximum chlorophylls content was obtained in $0.25 \mu \mathrm{M}$ isoproturon cultures, with values of 0.38 and $0.14 \mathrm{pg} \mathrm{cell}^{-1}$ of chlorophyll a content and chlorophyll bcontent, respectively, in comparison with the values obtained in control cultures (0.14 and 0.05 pg cell-1, respectively) ( Fig. 3). However, cells 
exposed to the highest isoproturon concentration assayed showed a decrease in these chlorophylls with respect to the $0.25 \mu \mathrm{M}$ cultures. Total carotenoid content was also increased, to $0.08 \mathrm{pg} \mathrm{cell-1}$ at the highest isoproturon concentration assayed $(P<0.05)$, while lower concentrations did not cause significant changes with respect to control cells $\left(0.03 \mathrm{pg}\right.$ cell-1$\left.^{-1}\right)$ ( Fig. 3).

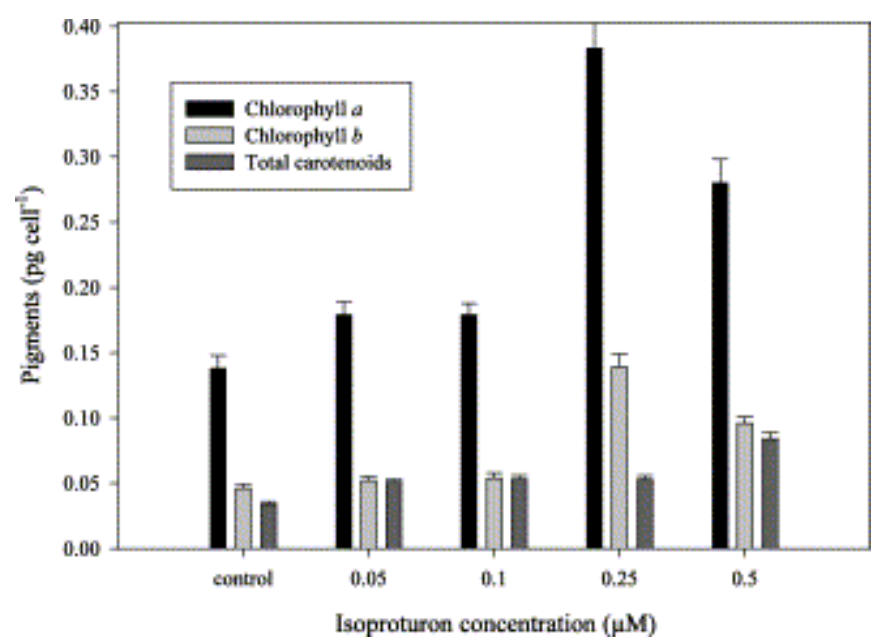

Fig. 3.

Photosynthetic pigments (chlorophylls $a$ and $b$, and total carotenoids), obtained from cultures of $C$. vulgaris exposed to different isoproturon concentrations $(\mu \mathrm{M})$ after $96 \mathrm{~h}$. Data are given as mean values \pm S.D. of the means.

\subsection{Terbutryn}

\subsubsection{Growth}

Growth of $C$. vulgaris cultures was affected by the addition of terbutryn to the medium ( Fig. 4; Table 2). After $48 \mathrm{~h}$ of herbicide exposure, the most important decrease in growth rate respect to control cultures was detected at terbutryn concentrations of 0.10 and $0.20 \mu \mathrm{M}(-0.06$ and 0.02 days $^{-1}$, respectively) $(P<0.05)$. After $96 \mathrm{~h}$ of herbicide exposure, higher terbutryn concentrations brought about an important decrease in growth rate, being close to zero with the maximum concentration assayed ( Table 2); however, the lowest concentration assayed provoked a significant increase of growth respect to control cultures (0.92 and 0.82 days $^{-1}$, respectively), which are not significant different to those cultures exposed to $0.05 \mu \mathrm{M}$ terbutryn. 


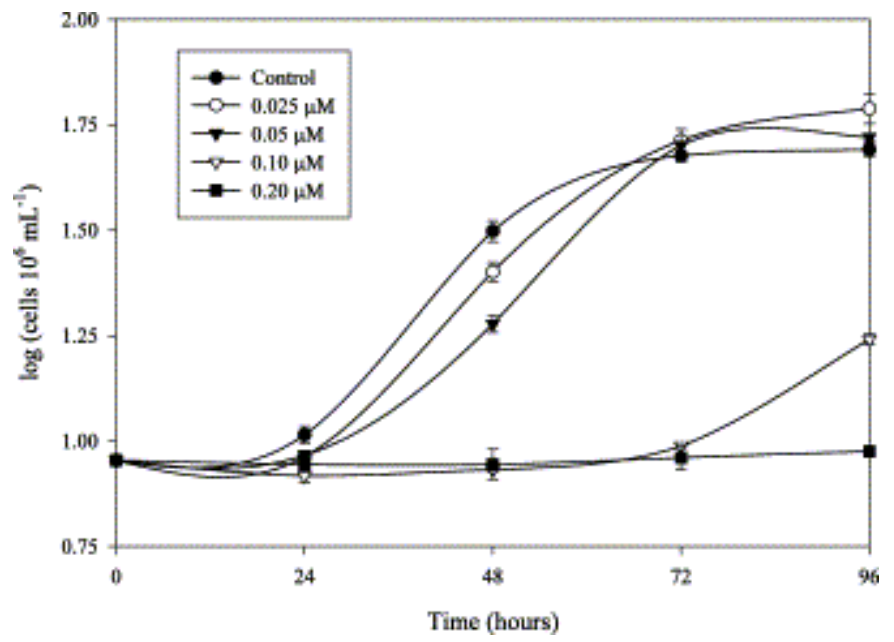

Fig. 4.

Growth curves of cultures of $C$. vulgaris exposed to different terbutryn concentrations $(\mu \mathrm{M})$. Data are given as mean values \pm S.D. of the means.

Table 2 .

Growth rate (GR) after 48 and 96 h, and dry weight, cell volume, protein content, and carbon/nitrogen ratio obtained in cultures of $C$. vulgaris exposed to different terbutryn concentrations after $96 \mathrm{~h}$

\begin{tabular}{lllllll}
$\begin{array}{l}\text { Terbutryn } \\
(\mu \mathrm{M})\end{array}$ & $\begin{array}{l}48 \mathrm{~h} \mathrm{GR}(\mu) \\
\left(\mathrm{day}^{-1}\right)\end{array}$ & $\begin{array}{l}96 \mathrm{~h} \mathrm{GR}^{-1}(\mu) \\
\left(\mathrm{day}^{-1}\right)\end{array}$ & $\begin{array}{l}\text { Dry weight } \\
\left(\mathrm{pg} \mathrm{cell}^{-1}\right)\end{array}$ & $\begin{array}{l}\text { Cell volume } \\
(\% \mathrm{FSC})\end{array}$ & $\begin{array}{l}\text { Protein } \\
\text { content }(\mathrm{pg}\end{array}$ & $\mathrm{C} / \mathrm{N}$ \\
cell $\left.^{-1}\right)$ & & \\
\hline 0 & $0.90 \pm 0.03$ & $0.82 \pm 0.01$ & $4.48 \pm 0.09$ & $100 \pm 0.08$ & $2.27 \pm 0.09$ & $5.54 \pm 0.06$ \\
\hline 0.025 & $0.74 \pm 0.03$ & $0.92 \pm 0.03$ & $4.33 \pm 0.33$ & $117 \pm 5.34$ & $2.25 \pm 0.10$ & $5.38 \pm 0.05$ \\
\hline 0.05 & $0.54 \pm 0.02$ & $0.85 \pm 0.01$ & $5.24 \pm 0.16$ & $124 \pm 12.40$ & $2.77 \pm 0.05$ & $5.31 \pm 0.1$ \\
\hline 0.10 & $-0.06 \pm 0.03$ & $0.32 \pm 0.01$ & $8.60 \pm 0.19$ & $153 \pm 11.30$ & $4.61 \pm 0.08$ & $5.15 \pm 0.19$ \\
\hline 0.20 & $-0.02 \pm 0.01$ & $0.02 \pm 0.00$ & $6.35 \pm 0.40$ & $147 \pm 10.10$ & $3.46 \pm 0.12$ & $4.93 \pm 0.09$
\end{tabular}

Data are given as mean values \pm standard desviation of the means.

Microalgal growth is characterized by a sigmoid or logistic function (Schanz and Zahler, 1981). Growth curves of the microalgal cultures exposed to the lowest terbutryn concentrations assayed $(0.025$ and $0.05 \mu \mathrm{M})$ were fitted to the parameters of a logistic function (Fig. 4). C. vulgaris cultures showed a prolonged lag phase after exposure to terbutryn, reaching the stationary phase later than control.

The concentration-response curves and their mathematical functions are shown in Fig. 5 In the terbutryn cultures, the $\mathrm{EC}_{50}$ value after $96 \mathrm{~h}$ of herbicide exposure was twice the $\mathrm{EC}_{50}$ for the cultures exposed $48 \mathrm{~h}$ to terbutryn (Fig. 5). 


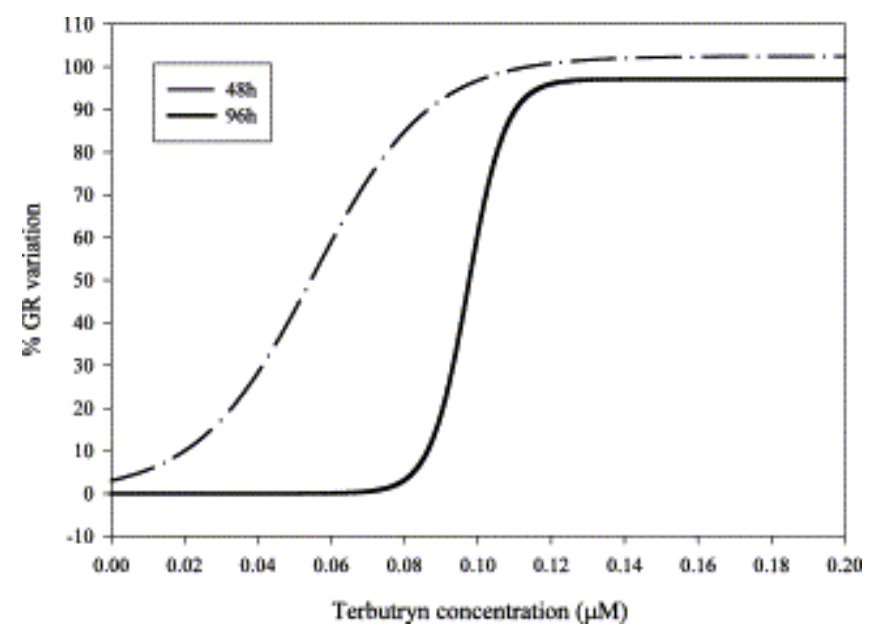

Fig. 5 .

Concentration-response curves represented by growth rate (GR) variation respect to the control of cultures of $C$. vulgarisversus different terbutryn concentrations $(\mu \mathrm{M})$ after 48 and $96 \mathrm{~h}$ of herbicide exposure. 48 h: $y=102.485 /\left(1+\exp (-(x-0.055) / 0.016)(r=0.99) \mathrm{EC}_{50}=0.055 ; 96 \mathrm{~h}: y=97.101 /(1+\exp (-(x-\right.$ $0.097) / 0.005)(r=0.99) \mathrm{EC}_{50}=0.097$

\subsubsection{Cell volume}

This herbicide also caused an increase in the FSC signal after $96 \mathrm{~h}$ of exposure. The highest concentrations tested $(0.10$ and $0.20 \mu \mathrm{M})$ caused the maximum increases $(P<0.05)$ of this signal (153 and 147\%, respectively) with respect to the control (100\%) ( Table 2).

\subsubsection{Dry weight, carbon/nitrogen ratio and protein content}

Concentrations of $0.05 \mu \mathrm{M}$ or higher provoked a significant increase $(P<0.05)$ in cellular dry weight, giving values in the range $5.25-8.60 \mathrm{pg}$ cell-1, in comparison with the value obtained in control culture cells (4.48 pg cell-1) ( Table 2$)$.

The $\mathrm{C} / \mathrm{N}$ ratio also decreased significantly $(\mathrm{P}<0.05)$ in cultures exposed to the highest terbutryn concentrations assayed, 0.10 and $0.20 \mu \mathrm{M}$ (5.15 and 4.96, respectively) relative to control cells (5.54) ( Table 2).

Terbutryn concentrations of $0.05 \mu \mathrm{M}$ or higher produced a significant increase $(P<0.05)$ in the protein content of the cells, after $96 \mathrm{~h}$ of exposure, being maximum at $0.10 \mu \mathrm{M}$ with a protein

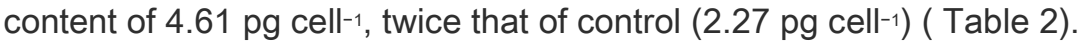

\subsubsection{Photosynthetic pigments content}

After $96 \mathrm{~h}$ of treatment, the two highest terbutryn concentrations $(0.10$ and $0.20 \mu \mathrm{M})$ brought about a significant increase both in chlorophylls and carotenoid contents of $C$. vulgaris cells with respect to the control cultures ( Fig. 6). 


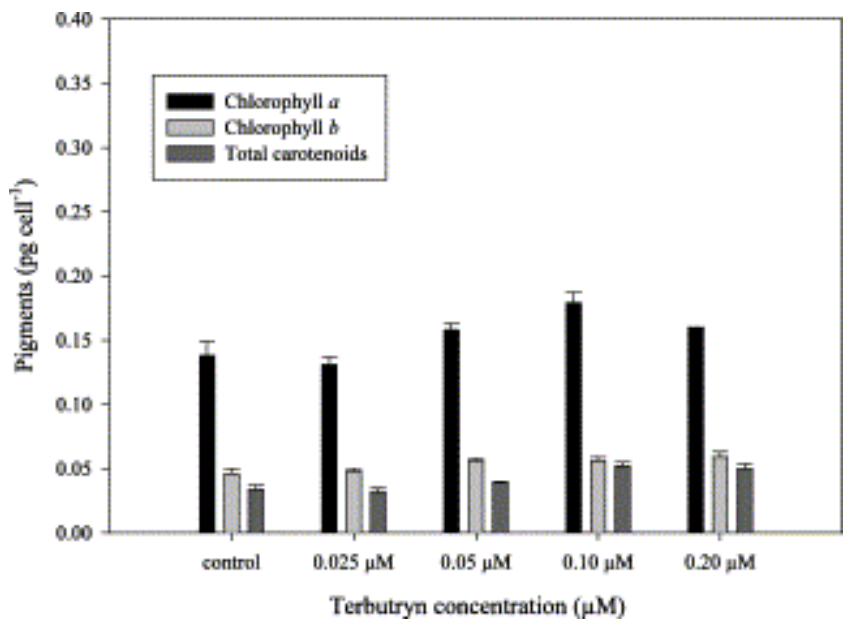

Fig. 6 .

Photosynthetic pigments (chlorophylls $a$ and $b$, and total carotenoids), obtained from cultures of $C$. vulgaris exposed to different terbutryn concentrations $(\mu \mathrm{M})$ after $96 \mathrm{~h}$. Data are given as mean values \pm S.D. of the means.

\section{Discussion}

Despite the fact that the effects of both herbicides might be similar, both of them are photosynthetic electron transport inhibitors, the growth response of $C$. vulgaris cultures was rather different. The not comparable effective concentrations indicate that uptake and mode of action of each herbicide could be different in $C$. vulgaris. The growth rate of microalgal cultures at 48 and $96 \mathrm{~h}$ shows that both herbicides have inhibitory effects at the highest concentrations assayed ( Table 1 and Table 2). Terbutryn is a more efficient inhibitor of growth of $C$. vulgaris cultures than isoproturon, since microalgal cultures exposed to isoproturon showed an $\mathrm{EC}_{50}$ value, after $96 \mathrm{~h}$ of treatment, twice that for the terbutryn-treated cultures( Fig. 2 and Fig. 5). $S$-Triazine herbicides, such as terbutryn, are considered one of the most efficient herbicides, at least when they are tested on freshwater algae ( Abou-Waly et al., 1991), probably due to the presence of a methylthio group in position six of the triazine ring, that could tend to be linked with the relatively high inhibitory effect to algal cells ( El-Dib et al., 1989). Moreover, differences in grade of toxicity can be associated with solubility of herbicides in lipids; it is well known that lipid-soluble substances easily pass into cells through the cell wall (Tang et al., 1998) and, that the sorption of the herbicide to algal cells is a prerequisite for its action at the chloroplast membrane. Isoproturon (log $K_{\text {ow }} 2.25$ ) can be considered a moderately lipophilic compound, but the triazine terbutryn ( $\log K_{\text {ow }} 3.49$ ) could be rapidly taken up, as a passive uptake, from the medium by $C$. vulgaris cells due to affinity of this molecule to the algal cell ( Reddy and Locke, 1996). This hypothesis will agree with the results obtained in the present work.

In C. vulgaris cultures, the $\mathrm{EC}_{50}$ value after $96 \mathrm{~h}$ of herbicide exposure is higher than the $\mathrm{EC}_{50}$ after $48 \mathrm{~h}$, for both herbicides assayed, suggesting that phytotoxicity of both herbicides at higher concentrations presents an acute action. Values obtained only after $48 \mathrm{~h}$ of toxic exposure can give a partial view of the facts occurring in the freshwater ecosystems. 
After herbicide exposure, the cells of $C$. vulgaris try to increase the growth rate after a inhibitory growth period, being its duration proportional to the herbicide concentration ( Table 1 and Table 2). Both growth curves and growth rates at 48 and $96 \mathrm{~h}$ show this phenomenon ( Fig. 1 and Fig. 4). Therefore, the herbicides assayed may have an algistatic effect.

It is outstanding that $96 \mathrm{~h} \mathrm{EC}_{50}$ values obtained for both herbicides are below the solubility limit in water for isoproturon $\left(65 \mathrm{mg} \mathrm{l}^{-1 ; 22}{ }^{\circ} \mathrm{C}\right.$ ) and, terbutryn (22 mg l-1; $\left.20^{\circ} \mathrm{C}\right)$ (Cremlyn, 1991), concentrations susceptible of affecting algal growth. Generally, PS II herbicide concentrations are below $0.1 \mu \mathrm{g} \mathrm{I}^{-1}$ (limit value for drinking waters, at least in european countries) (El Jay et al., 1997). However, several aquatic systems have been found to be contaminated with higher concentrations; for instance, herbicide concentrations higher than $2 \mu \mathrm{g} \mathrm{I}^{-1}$ have been found in several rivers of Europe (Beitz et al., 1994). This suggests that important effects would be caused on microalgae populations after herbicide application, leading to the disappearance of different species, as $C$. vulgaris, an ubiquous, constitutive and generally defined as a tolerant species of the plankton community in freshwater environments (Kasai and Hanazato, 1995).

The lowest concentrations assayed of the triazine herbicide causes an increase in the cellular density and growth rate of the test microalga after $96 \mathrm{~h}$ of exposure, not observed in the phenylurea herbicide-treated cultures (Table 2; Fig. 4). Stimulation effects are often recorded in algal bioassays with different species and different pesticides (El-Dib et al., 1991; Haglund, 1997; Franqueira et al., 1999). This stimulation of growth, obtained at the lowest terbutryn concentrations, indicates the ability of algal cells, and especially of $C$. vulgaris, to adapt and resist the inhibitory effect of herbicides. This may explain the increase observed in algae in herbicide-treated aquatic ecosystems and perhaps also in aquatic ecosystems subjected to toxicants ( Shehata et al., 1997).

Dry weight and cell volume of $C$. vulgaris cells strongly increased in the presence of the highest concentrations of the two herbicides assayed, especially in the phenylurea cultures ( Table 1 and Table 2).

These increases may be related to the growth inhibition at the highest herbicide concentrations. These two parameters showed a positive correlation for isoproturon and terbutryn ( $r=0.90$ and 0.85 , respectively). Photosynthesis-inhibiting herbicides may alter the overall bioenergetic status of the plant ( Wilson et al., 2000), leading to the uncoupling of cell growth and reproductive processes, as reflected in the increase in the dry weight or the cell volume. Previous studies indicate that cell volume are correlated significantly with toxicity ( Tang et al., 1998). It is important that this increase in dry weight and cell volume may influence the remaining parameters, pigment and protein content ( Table 1 and Table 2; Fig. 3 and Fig. 6).

Since the herbicides assayed specifically exert its phytotoxic action at the photosystem II level, changes in microalgal chlorophyll content can be a reliable indicator of toxicity (Mayer et al., 1997); but the results suggest that these herbicides may affect chlorophyll and growth differently. In this study, at the concentrations of herbicides that provoke an inhibition of microalgal growth, chlorophyll content per cell is increased (Fig. 3 and Fig. 6). 
Examples of triazine-induced increases of the algal chlorophyll content were reported in Selenastrum capricornutum by Mayer and Jensen (1995). It can be interpreted as a tolerance mechanism ( François and Robinson, 1990). This process may result from a homeostatic mechanism triggered by the exposure to the herbicides. Responses such as the synthesis of thylakoid components are considered to be a general adaptation response to situations in which electron transport rate is strongly limited for photosynthesis ( Behra et al., 1999). The $\mathrm{C} / \mathrm{N}$ ratio decreased as herbicides concentrations increased (Table 1 and Table 2).

As a result of the photosynthetic inhibition process, microalgal cells would not have enough energy for $\mathrm{CO}_{2}$ fixation. This can be the reason why $\mathrm{C}$ content decreases in the cultures after 96 $\mathrm{h}$ of exposure to both herbicides assayed.

Since proteins were determined from the data of nitrogen content, the increase recorded in the cellular protein content may be provoked by the increase obtained in the cellular contents of $\mathrm{N}$, and then can be explained by the increase of dry weight and cell volume (Table 1 and Table 2). An increase in protein content could be also related with a detoxification mechanism, for instance other herbicides as simazine have been shown to be detoxified by various microalgal species and subsequent binding to a protein (Kruglov, 1970).

\section{Acknowledgements}

This work was supported by a research project from Xunta de Galicia (Spain) (ref. PGIDT01MAM10302PR). C. Rioboo holds a fellowship from the Plan Nacional F.P.U., Ministerio de Educación y Cultura, Madrid, Spain. O. González holds a fellowship from the Consellería da Presidencia, Xunta de Galicia (Spain). Thanks to the anonimous referees of this paper that contributed to improve it.

\section{References}

H. Abou-Waly, M.M. Abou-Setta, H.N. Nigg, L.L. Mallory

Growth response of freshwater algae Anabaena flos-aquae and Selenastrum capricornutum to atrazine and hexazinone herbicides

Bull. Environ. Contam. Toxicol., 46 (1991), pp. 223-229

R. Behra, G.P. Genoni, A.L. Joseph

Effects of atrazine on growth, photosynthesis, and between-strain variability in Scenedesmus subspicatus (Chlorophyceae)

Arch. Environ. Contam. Toxicol., 37 (1999), pp. 36-41

H. Beitz, H. Schmidt, F. Herzel

Occurrence, toxicological and ecotoxicological significance of pesticides in groundwater and surface waters

W. Ebing (Ed.), Pesticides in Ground and Surface Water, Springer-Verlag, New York (1994), pp. 279-314

T.E. Brown, F.L. Richardson, M.L. Vaughn 
Development of red pigmentation in Chlorococcum wimmeri (Chlorophyta: Chlorococcales)

Phycologia, 6 (1967), pp. 167-184

P.-Y. Caux, L. Ménard, R.A. Kent

Comparative study of the effects of MCPA, butylate, atrazine, and cyanazine on Selenastrum capricornutum

Environ. Pollut., 92 (1996), pp. 219-225

R.J. Cremlyn

Agrochemicals: Preparation and Mode of ActionWiley, New York (1991)

M.A. El-Dib, S.A. Shehata, H.F. Abou-Waly

Response of freshwater alga Scenedesmus to triazine herbicides

Water Air Soil Poll., 48 (1989), pp. 307-316

M.A. El-Dib, A. Shehata, H.F. Abou-Waly

Response of freshwater algae (Scenedesmus sp.) to phenylurea herbicides

Water Air Soil Poll., 55 (1991), pp. 295-303

E. El Jay, J.M. Ducruet, J.C. Duval, J.P. Pelletier

A high-sensitivity chlorophyll fluorescence assay for monitoring herbicide inhibition of photosystem II in the chlorophyte Selenastrum capricornutum: comparison with effect on cell growth

Arch. Hydrobiol., 2 (1997), pp. 273-286

FAO/WHO, 1973. Amino acid content of foods and biological data on proteins, vol. 24, Rome, Italy.

François and Robinson, 1990

D.L. François, G.G.C. Robinson

Indices of triazine toxicity in Chlamydomonas geitleri Ettl

Aquat. Toxicol., 16 (1990), pp. 205-228

D. Franqueira, A. Cid, E. Torres, M. Orosa, C. Herrero

A comparison of the relative sensitivity of structural and functional cellular responses in the alga Chlamydomonas eugametos exposed to the herbicide paraquat

Arch. Environ. Contam. Toxicol., 36 (1999), pp. 264-269

E. Gnaiger, G. Bitterlich

Proximate biochemical composition and caloric content calculated from elemental $\mathrm{CHN}$ analysis: a stoichiometric concept

Oecologia, 62 (1984), pp. 289-298

K. Haglund

The use of algae in aquatic toxicity assesment

,in: F.E. Round, D.J. Chapman (Eds.), Progress in Phycological Research, 12Biopress, Bristol, UK (1997), pp. $181-212$ 
F. Kasai, T. Hanazato

Effects of the triazine herbicide, simetryn, on freshwater plankton communities in experimental ponds

Environ. Pollut., 89 (1995), pp. 197-202

Y.V.a.E.I.P. Kruglov

Detoxification of simazine by microscope algae

Mikrobiologiya, 39 (1970), pp. 157-160

L. Larsen, S.R. Sorensen, J. Aamand

Mecroprop, isoproturon, and atrazine in and above a sandy aquifer: vertical distribution of mineralization potential

Environ. Sci. Technol., 34 (2000), pp. 2426-2430

H.K. Lichtenthaler

Chlorophylls and carotenoids: pigments of photosynthetic biomembranes

Methods Enzymol., 148 (1987), pp. 350-382

Mayer, P., Jensen, J.F., 1995. Factors affecting results of algal toxicity tests. In: Institute for Environmental Science and Technology, Technical University of Denmark, Lyngby.

Mayer et al., 1997

P. Mayer, R. Cuhel, N. Nyholm

A simple in vitro fluorescence method for biomass measurements in algal growth inhibition tests

Water Res., 31 (1997), pp. 2525-2531

P.V. McCormick, J.J. Cairns

Algae as indicators of environmental change

J. Appl. Phycol., 6 (1994), pp. 509-526

C. Nalewajko, M.M. Olaveson

Ecophysiological considerations in microalgal toxicity tests

P.G. Wells, K. Lee, C. Blaise (Eds.), Microscale Testing in Aquatic Toxicology. Advances, Techniques and Practice, CRC Press, Boca Raton, FL (1998), pp. 289-309

F. Pérés, D. Florin, T. Grollier, A. Feurtet-Mazel, M. Coste, F. Ribeyre, M. Ricard, A. Boudou

Effects of the phenylurea herbicide isoproturon on periphytic diatom communities in freshwater indoor microcosms

Environ. Pollut., 94 (1996), pp. 141-152

\section{S. Reader, M. Marion, F. Denizeau}

Flow cytometric analysis of the effects of tri-n-butyltin chloride on cytosolic free calcium and thiol levels in isolated rainbow trout hepatocytes

Toxicology, 80 (1993), pp. 117-129 
K. Reddy, M.A. Locke

Molecular properties as descriptors of octanol-water partition coefficients of herbicides

Water Air Soil Poll., 86 (1996), pp. 389-405

F. Schanz, U. Zahler

Prediction of algal growth in batch cultures

Schweiz. Z. Hydrol., 43 (1981), pp. 103-113

H.M. Shapiro

Practical Flow Cytometry (3rd ed.)Wiley-Lyss, New York (1995)

S.A. Shehata, M.A. El-Dib, H.F. Abou-Waly

Effect of certain herbicides on the growth of freshwater algae

Water Air Soil Poll., 100 (1997), pp. 1-12

S. Singh, R.C. Kirkwood, G. Marshall

Effects of isoproturon on photosynthesis in susceptible and resistant biotypes of Phalaris minor and wheat Weed Res., 37 (1997), pp. 315-324

B. Sosak-Swiderska, D. Tyrawska, B. Maslikowska

Microalgal ecotoxicity test with 3,4-dichloroaniline

Chemosphere, 37 (1998), pp. 2975-2982

J. Tang, K.D. Hoagland, B.D. Siegfried

Uptake and bioconcentration of atrazine by selected freshwater algae

Environ. Toxicol. Chem., 17 (1998), pp. 1085-1090

C. Tomlin

The Pesticide Manual. A World Compendium, The Bath Publisher, Bath (1994), p. 1341

S.D. Utting

Influence of nitrogen availability on the biochemical composition of three unicellular marine algae of commercial importance

Aquacult. Eng., 4 (1985), pp. 175-190

G.E. Walsh, R.G. Merril

Algal bioassays of industrial and energy process effluents

L.E. Shubert (Ed.), Algae as Ecological Indicators, Academic Press, London (1984), pp. 329-360

P.C. Wilson, T. Whitwell, S.J. Klaine

Phytotoxicity, uptake, and distribution of 14C-simazine in Acorus gramenius and Pontederia cordata Weed Sci., 48 (2000), pp. 701-709

Corresponding author. Tel.: +34-981-167-000; fax: +34-981-167-065 
Copyright $\odot 2002$ Elsevier Science B.V. All rights reserved. 